\title{
ANTICANCER EFFECTS OF SELENIUM COMPOUNDS ON HUMAN COLONIC CARCINOMA CELLS
}

\author{
LJ. GLAVAŠ-OBROVAC ${ }^{\mathrm{a}}$, T. KLAPEC ${ }^{\mathrm{b}, \mathrm{c}}$, M. L. MANDIC ${ }^{\mathrm{b}}$ and I. KARNER ${ }^{\mathrm{a}}$ \\ ${ }^{a}$ Clinical Hospital, Department of Nuclear Medicine, Huttlerova b.b., HR-31000 Osijek. Croatia \\ ${ }^{b}$ University J. J. Strossmayer in Osijek, Faculty of Food Technology, Department of Food Quality Control \\ and Nutrition, Kuhaceva 18, HR-31107 Osijek. Croatia
}

(Received: 22 December 1999; accepted: 26 March 2000)

\begin{abstract}
Studies performed so far on different human carcinoma cell lines, as well as numerous case-control and epidemiological studies have given proof to the protective effects of selenium against cancer. However, the anticancer properties of selenium are site-specific. The aim of this work was to evaluate the cytotoxic effect of selenium against $\mathrm{CaCo} 2$ human colon carcinoma cells, and SW620 lymph node metastasis of colon carcinoma cell line. Three selenium compounds, seleno-DL-cystine $(\mathrm{SeC})$, seleno-L-methionine $(\mathrm{SeM})$ and sodium selenite were used. Initial number of cells was $2 \times 10^{4}$ and the cells were incubated for $72 \mathrm{~h}$ with the aforementioned Se compounds at 10,100 and $1000 \mu \mathrm{mol}$ Se concentrations. Cytotoxicity was measured by the MTT cell survival assay. In the present study, decreased viabilities of both $\mathrm{CaCo} 2$ and SW620 cells were established following the treatment with selenite, $\mathrm{SeC}$, and $\mathrm{SeM}$. At $10 \mu \mathrm{mol}$ Se levels all three chemical forms exerted a more or less anticipated cytotoxic effect with viability decreases ranging from 22 to $37 \%$. However, the other two levels of 100 and $1000 \mu \mathrm{mol}$ Se did not exhibit an expected proportional rise in cytotoxic effect compared to $10 \mu \mathrm{mol}$, which warrants further research on the reasons for increased resistance of these cells. Cell morphology also indicates that investigated Se forms induced apoptotic cell death in both cell lines. The results confirm the applicability of Se in the prevention and treatment of the investigated cancer sites.
\end{abstract}

Keywords: selenium, cytotoxicity, colonic carcinoma

A great body of evidence for the protective role of selenium against cancer has accumulated over the last three decades, ever since the first ecological studies have suggested an inverse relationship between selenium concentration in soil, food, and/or blood and cancer incidence (Allaway et al., 1968; Shamberger \& Frost, 1969; SCHAMBERGER \& Willis, 1971; SCHRAUZER et al., 1977). Selenium's anticancer properties have also been extensively investigated in numerous case-control and epidemiological studies, most of which support the hypothesis that this microelement is an indispensable risk factor for cancer (MCCONNELL et al., 1975; SALONEN et al., 1984;

${ }^{c}$ To whom the correspondence should be addressed. E-mail: tomi@ptfos.hr 
COMSTOCK et al., 1992; RUMI et al., 1992). Probably the most convincing epidemiological proof to the hypothesis is the intervention trial in which total cancer mortality in the selenium-supplemented group was 50\% less than in the control group (CLARK et al., 1996). Various selenium compounds have also been demonstrated to inhibit chemically and virally-induced carcinogenesis, both in cell culture and in vivo (SCHRAuZER et al., 1978; MEDINA \& SHEPHERD, 1980; THOMPSON \& BECCI, 1980; MEDinA et al., 1983; Milks et al., 1985; LiAO et al., 1988; APPEL \& WOUTERSEN, 1996), as well as UVR-induced skin carcinogenesis (OVERVAD et al., 1985). The protective effects of selenium have been established in both the initiation and promotion phases of carcinogenesis (THOMPSON \& BECCI, 1980; APPEL \& WOUTERSEN, 1996). Additionally, selenium completely inhibits cancer propagation, according to GREEDER and MiLNER (1980) who examined the effect of selenium on mice with Ehrlich ascites tumors. Many mechanisms for the anticarcinogenic and anticancer properties of selenium have been proposed, including its antioxidant activity through selenium containing glutathione peroxidase (GPX), involvement in carcinogen metabolism affecting cytochrome P-450, inhibition of certain enzymes, stimulation of apoptosis, inhibition of protein synthesis, modulation of endocrine and immune responses, etc. (MILNER, 1985; IP, 1986; El-BAYOUMY, 1991). Cell culture experiments have provided most of the current knowledge on mechanisms of the element's anticancer activity. Some selenium compounds are genotoxic while others are not, but both groups inhibit growth of different cell lines (LU et al., 1995; STEWART et al., 1999). The extent of the determined cytotoxic and antiproliferative effects of selenium depends on both the selenium chemical form and the investigated cell line. It has been observed before that the strength of selenium's protective activity may be site-specific in humans, and the best evidence is in relation to cancers of colon, rectum and other gastro-intestinal carcinomas (CLARK, 1985; CLARK et al., 1996).

The aim of this study was to examine the cytotoxic effects of three different forms of selenium in two human cancer cell lines, $\mathrm{CaCo} 2$ human colon carcinoma and $\mathrm{SW620}$ lymph node metastasis of colon carcinoma.

\section{Materials and methods}

\subsection{Cell lines and culture}

Human colon carcinoma cells $(\mathrm{CaCo} 2)$ and poorly differentiated cells from lymph node metastasis of colon carcinoma (SW620) were kindly provided by Professor Krešimir Pavelić (Division of Molecular Medicine, Ruder Bošković Institute, 
Zagreb, Croatia), and were grown in DME medium which was supplemented with $10 \%$ fetal bovine serum, $2 \mathrm{mmol}$ L-glutamine, $100 \mathrm{IU} \mathrm{ml}^{-1}$ penicillin and $100 \mathrm{mg} \mathrm{ml}^{-1}$ streptomycin. The cultures were equilibrated with humidified $5 \% \mathrm{CO}_{2}$ in air at $37^{\circ} \mathrm{C}$.

The effects of the investigated forms of selenium on $\mathrm{CaCo} 2$ and $\mathrm{SW} 620$ cell morphology were also studied by light microscopy.

\subsection{Cell viability assay}

The quantity of cells was determined using the tetrazolium dye (MTT) test, as described previously by HORIUCHI and co-workers (1988). CaCo2 and SW620 cells $\left(2 \times 10^{4} \mathrm{cells} / \mathrm{ml}\right)$ were plated onto $96-$ microwell plates. The tested selenium compounds were sodium selenite, seleno-DL-cystine $(\mathrm{SeC})$, and seleno-L-methionine ( $\mathrm{SeM})$. They were added to the cells at 10,100 and $1000 \mu \mathrm{mol}$ selenium concentrations, respectively, $24 \mathrm{~h}$ after plating. After 3 days of incubation, the cells were stained with $20 \mu \mathrm{l}$ of $5 \mathrm{mg} \mathrm{ml}^{-1}$ MTT in phosphate buffered saline for $4 \mathrm{~h}$. The precipitate was solubilized with $50 \mu \mathrm{l}$ DMSO and the plates were read with an Elisa reader at $570 \mathrm{~nm}$. All experiments were performed at least 2 times with 6 wells for each.

\subsection{Determination of DNA synthesis}

DNA synthesis in $\mathrm{CaCo} 2$ cells was determined using ${ }^{3} \mathrm{H}$-thymidine incorporation assay. Six hours before end of 3-day culturing, ${ }^{3} \mathrm{H}$-thymidine $\left(25 \mathrm{mCi} \mathrm{ml}^{-1}\right)$ was added to a final concentration of $1 \mu \mathrm{Ci} \mathrm{ml}^{-1}$. The cells were harvested onto glass wool filters using a cell harvester and the incorporated radioactivity was measured in a scintillation counter.

\section{Results}

\subsection{Cytotoxicity}

The results of cell viability assay are given in Table 1 . The survival of both $\mathrm{CaCo} 2$ and SW620 cells decreased with the increasing concentration of selenite, $\mathrm{SeC}$ and SeM, respectively.

\subsection{DNA synthesis}

Incorporation of radioactive precursor ${ }^{3} \mathrm{H}$-thymidine was only monitored in $\mathrm{CaCo} 2$ cells at 10 and $100 \mu \mathrm{mol}$ selenium concentrations, and the results are given in Table 2. A dose-dependent decrease of DNA synthesis was observed, consistent with the results of the MTT-test. 
Table 1

Effects of selenite, selenocysteine and selenomethionine on the viability of SW620 and CaCo2 cells ${ }^{a}$

\begin{tabular}{lcc}
\hline Treatment & SW620 & CaCo2 \\
\hline None & 100 & 100 \\
Selenite, $10 \mu \mathrm{mol}$ & $74.5 \pm 3.5$ & $63.1 \pm 2.5$ \\
Selenite, $100 \mu \mathrm{mol}$ & $59.1 \pm 2.7$ & $58.4 \pm 1.7$ \\
Selenite, $1000 \mu \mathrm{mol}$ & $54.8 \pm 3.9$ & $50.2 \pm 3.2$ \\
Selenocysteine, $10 \mu \mathrm{mol}$ & $63.1 \pm 1.9$ & $66.9 \pm 7.9$ \\
Selenocysteine, $100 \mu \mathrm{mol}$ & $61.2 \pm 0.8$ & $62.8 \pm 1.7$ \\
Selenocysteine, $1000 \mu \mathrm{mol}$ & $56.2 \pm 4.8$ & $44.9 \pm 16.5$ \\
Selenomethionine, $10 \mu \mathrm{mol}$ & $68.2 \pm 2.1$ & $77.9 \pm 1.7$ \\
Selenomethionine, $100 \mu \mathrm{mol}$ & $60.4 \pm 3.1$ & $64.8 \pm 2.6$ \\
Selenomethionine, $1000 \mu \mathrm{mol}$ & $60.2 \pm 3.6$ & $58.2 \pm 3.7$ \\
\hline
\end{tabular}

${ }^{\text {a }}$ data are mean percentages of live cells $\pm \mathrm{SD}$

Table 2

Effects of selenite, selenocysteine and selenomethionine on DNA synthesis in CaCo2 cells

\begin{tabular}{lc}
\hline Treatment & $\begin{array}{c}\text { \% Incorporation of } \\
\text { 3 H-thymidine }\end{array}$ \\
\hline None & 100 \\
Selenite, $10 \mu \mathrm{mol}$ & 63.6 \\
Selenite, $100 \mu \mathrm{mol}$ & 57.9 \\
Selenocysteine, $10 \mu \mathrm{mol}$ & 71.7 \\
Selenocysteine, $100 \mu \mathrm{mol}$ & 53.9 \\
Selenomethionine, $10 \mu \mathrm{mol}$ & 68.2 \\
Selenomethionine, $100 \mu \mathrm{mol}$ & 61.4 \\
\hline
\end{tabular}

\section{Discussion}

The well-documented anticarcinogenic and antitumor action of Se cannot be fully explained by the antioxidant activity of GPX (DAVIS et al., 1999; STEWART et al., 1999). The link between thioredoxin reductase and anticancer activity of selenium has not been elucidated as yet. The selenium-containing enzyme reduces thioredoxin which stimulates cell growth and is overexpressed in cancer cells (POWIS et al., 1997; BERGGREN et al., 1999). The cytotoxic activity of Se has been the focus of the research 
concerned with its antitumor properties. Selenium compounds exert this activity differently and with varying efficacy. In the present study the cytotoxic effects of selenite, $\mathrm{SeC}$ and $\mathrm{SeM}$ were established against $\mathrm{CaCo} 2$ and SW620 cells. At $10 \mu \mathrm{mol} \mathrm{Se}$ levels all three chemical forms exerted a more or less expected cytotoxic effect with viability decreases ranging from 22 to $37 \%$ (Table 1). However, the other two levels of 100 and $1000 \mu \mathrm{mol}$ Se caused a minor increase in the cytotoxic effect compared to $10 \mu \mathrm{mol}$ which is especially evident in SW620 cells. None of the forms precipitated a $50 \%$ decrease in viability after $72 \mathrm{~h}$ of exposure of this cell line to Se (Table 1). The percentage of $\mathrm{CaCo} 2$ cell viability decrease reached $50 \%$ at $1000 \mu \mathrm{mol}$ selenite-Se, while the same concentration of $\mathrm{SeC}$ decreased the number of viable $\mathrm{CaCo} 2$ cells by $55 \%$. The unexpectedly low cytotoxic effects of selenite, $\mathrm{SeC}$ and $\mathrm{SeM}$ at 100 and $1000 \mu \mathrm{mol}$ Se in both investigated cell lines could be an indication of their adaptation to high Se concentrations, as observed before in a relatively Se-insensitive cell line (FICO et al., 1986). It has also been established (FEARON \& VOGELSTEIN, 1990) that p53 gene is usually mutated in colonic carcinoma cells, which disables the p53-dependent apoptosis or programmed cell death. The absence of p53 expression produces a dramatic increase in resistance of such cells to anticancer agents (LOWE et al., 1993).

Most other authors who investigated selenite-Se cytotoxicity on different cell lines with a dye exclusion test reported lower concentrations of selenite required to induce a $50 \%$ decrease in cell viability (i.e. $\mathrm{IC}_{50}$ value). This can, in part, be explained by study design to assess selenium cytotoxicity, implying different duration of treatment, plating density, etc. In HL-60 human leukemia cells the viability fell to $50 \%$ of control at $34 \mu \mathrm{mol}$ selenite level (BATIST et al., 1986). FICO and co-workers (1986) determined $97,52,40$, and $18 \%$ decreased viabilities in different canine mammary tumor cell lines after $72 \mathrm{~h}$ of incubation with $10 \mu \mathrm{mol}$ of Se as selenite. Selenite was also shown to be very cytotoxic to mouse keratinocyte BALB/c MK2 cell line after 24-h incubation at $317 \mu \mathrm{M}$ (STEWART et al., 1999). No viable cells were detected at that and higher levels. Cell viabilities were decreased 12 and $40 \%$ in B16 murine melanoma cells at 10 and $100 \mu \mathrm{mol}$ selenite-Se concentrations, respectively (SIWEK et al., 1994). In pB16 cells the corresponding viability decreases were 39 and $54 \%$.

The cytotoxicity of selenite is based on its ability to generate superoxide and oxidative free radicals which have been shown as capable of inducing cell death (GARBERG et al., 1988; HOCKENBERY et al., 1993; SpAllHOLZ, 1994). Selenite reacts with glutathione (GSH), as well as other thiol-containing proteins, to give selenodiglutathione (SDG) (i.e. corresponding selenotrisulfides; RSSeSR) (GANTHER, 1968), which is an even more potent inhibitor of cell growth in vitro than selenite itself (FICO et al., 1986; CAFFREY \& FRENKEL, 1991; LANFEAR et al., 1994). SDG is then reduced to a selenopersulfide anion $\left(\mathrm{GS}^{-} \mathrm{Se}^{-}\right.$) which in turn redox cycles producing free radicals. Several groups of authors observed a genotoxic effect as a result of selenite- 
induced redox cycling in different cell lines (GARBERG et al., 1988; WILSON et al., 1992; SINHA et al., 1996; STEWART et al., 1999). It has been reported that concentrations of $10 \mu \mathrm{mol}$ selenite and higher induce apoptotic cell death (ZHU et al., 1996; STEWART et al., 1997). The induction of apoptosis is attributed to the free radical oxidative stress by the oxidation of cellular GSH (DAVIS \& SPALLHOLZ, 1996), and to the endonuclease activation (LU et al., 1994). However, some authors suggested the involvement of a Se-binding protein in growth inhibition by selenium (WU et al., 1995), while others propose conversion of selenite to methylated compounds which indiscriminately bind to proteins and nucleic acids (IP \& GANTHER, 1990; IP et al., 1991; WILSON et al., 1992; IP \& GANTHER, 1993).

$\mathrm{SeC}$ was more effective than selenite in decreasing survival of B16 cells in an MTT-assay (SIWEK et al., 1994). At 10 and $100 \mu \mathrm{mol} \mathrm{SeC} \mathrm{concentrations} \mathrm{the} \mathrm{viabilities}$ of B16 cells were decreased by 22 and $87 \%$, respectively. The amount of living pB16 cells at these $\mathrm{SeC}$ levels dropped by 34 and $65 \%$, respectively. Although $10 \mu \mathrm{mol} \mathrm{SeC}$ caused a stronger cytotoxic effect in both SW620 and $\mathrm{CaCo} 2$ cells (Table 1) than in both B16 or pB16 cells, a significant decrease in cell viability occurred in these cells at $100 \mu \mathrm{mol}$ level which could not be seen in either SW620 or $\mathrm{CaCo} 2$ cells. A dose-dependent response exists but the lack of a more pronounced effect of both selenite and $\mathrm{SeC}$ as documented by most other researchers is difficult to explain. $\mathrm{SeC}$ decreased the number of viable $\mathrm{L} 1210$ cells by $29 \%$ after $3 \mathrm{~h}$ incubation at $6.33 \mu \mathrm{mol}$ (MILNER \& HSU, 1981), while the determined IC $_{50}$-value for HL-60 cells was $10.5 \mu \mathrm{mol}$ (BATIST et al., 1986).

Similarly to selenite, $\mathrm{SeC}$ reacts with GSH to give selenocysteine which is then enzymatically converted to $\mathrm{H}_{2} \mathrm{Se}$ by the enzyme selenocysteine lyase (DICKSON \& TAPPEL, 1969; ESAKI et al., 1982). Involvement of selenide anions $\left(\mathrm{Cy}^{-} \mathrm{Se}^{-}\right)$is implicated in the cytotoxicity of SeC (WhITING et al., 1980). Moreover, it has been suggested that the prooxidant catalytic action of Se is limited to the forms which can generate the selenide anion (R-Se ${ }^{-}$) (YAN \& Spallholz, 1993; Spallholz, 1994). The established lesser cytotoxicity and genotoxicity of $\mathrm{SeC}$ compared with selenite is attributed to the lower reactivity of the C-bonded selenide group of $\mathrm{SeC}\left(\mathrm{Cy}-\mathrm{Se}^{-}\right)$than the S-bonded selenide anion of selenopersulfide (GS-Se ${ }^{-}$) from inorganic Se compounds (ShAmberGer, 1985). Both selenite and SeC can deplete cellular GSH levels (ANUNDI et al., 1984; YAN et al., 1991; STEWART et al., 1997). GSH is needed for the cytotoxic effect of selenite and $\mathrm{SeC}$, since the reaction between these molecules is the first step in the metabolic conversion of selenite and $\mathrm{SeC}$ to Se species which redox cycle producing reactive free radicals and peroxides (CAFFREY \& FRENKEL, 1991; YAN \& SPAllHOlZ, 1993). GSH can also give significant protection against reactive oxygen species (ARRICK \& NATHAN, 1984). 
In SW620 cells, $10 \mu \mathrm{mol}$ SeM-Se induced a $31.8 \%$ drop in cell viability which is better than its reported activity in UACC-375 melanoma or MCF-7/S breast cancer cells and similar to DU-145 prostate cancer cell line (REDMAN et al., 1998). The effect of SeM in SW620 cells did not increase significantly at 100 and $1000 \mu \mathrm{mol}$, not reaching $50 \%$ survival decrease (Table 1). Similar pattern was observed with SeM addition to $\mathrm{CaCo} 2$ cells. Most authors who investigated SeM cytotoxicity determined the $\mathrm{IC}_{50}$ of 40 to $320 \mu \mathrm{mol}$ (PORTER et al., 1984; KAJANDER et al., 1990; REDMAN et al., 1998). In contrast, SeM induced only a small decrease of cell survival in B16 and pB16 cells at 10 and $100 \mu \mathrm{mol}$ levels (around 10 and $5 \%$ for B16, and around $20 \%$ at both levels for pB16 cells) (SIWEK et al., 1994). SeM was neither toxic to HL-60 cells up to $100 \mu \mathrm{mol}$ (BATIST et al., 1986) nor to BALB/c MK2 mouse keratinocyte cell line up to $3170 \mu \mathrm{mol}$ (STEWART et al., 1999).

SeM is metabolized via the transsulfuration mechanism to selenocysteine, and then enzymatically to $\mathrm{H}_{2} \mathrm{Se}$, as already mentioned above. Considering very similar metabolic pathways, the consistently weaker cytotoxic effects of SeM compared to $\mathrm{SeC}$ are somewhat surprising (YAN et al., 1991; SIWEK et al., 1994). In part, this can be explained by the non-specific incorporation of SeM into proteins in place of methionine (IP \& GANTHER, 1993). On the basis of their results, STEWART and co-workers (1999) consider SeM a relatively non-toxic and non-redoxing form of Se. REDMAN and coworkers $(1997 ; 1998)$ have shown that SeM induces cell death by apoptosis which is independent of $\mathrm{p} 53$. They also suggested that depletion of polyamines by SeM leads to an apoptotic cell death and cell cycle changes.

There were no significant differences between the effects of selenite, $\mathrm{SeC}$ and SeM on cell morphology. After $24 \mathrm{~h}$ of treatment, the majority of cells became smaller, round shaped, and a proportion of cells spontaneously detached from the culture flask and floated in the medium. The apoptotic characteristics of cytoplasmic vacuolization and chromation condensation were also observed in both cell lines after 24-h treatment with the three forms of Se.

The measurement of the rate of DNA synthesis in the presence of the three Se forms reveals their growth inhibitory effect on $\mathrm{CaCo} 2$ cells (Table 2). There is no significant difference between selenite, $\mathrm{SeC}$ and $\mathrm{SeM}$ at $10 \mu \mathrm{mol}$ Se level. At $100 \mu \mathrm{mol}$ there is a slightly stronger effect of selenite and $\mathrm{SeC}$ evident, in comparison with $\mathrm{SeM}$ (Table 2). ABDUlLaeV and GonZALEZ De MeIJA (1996) reported similar inhibitory effect $(70 \%$ of control) on DNA synthesis in HeLa cells after 1-h treatment with $10 \mu \mathrm{mol}$ selenite. In MOD cells, however, after $24 \mathrm{~h}$ of Se treatment, $10 \mu \mathrm{mol}$ selenite reduced DNA synthesis by more than $90 \%$ (LU et al., 1995).

In spite of the lack of a proportional drop of cell survival beyond $10 \mu \mathrm{mol} \mathrm{Se}$, which warrants further research on these cell lines, the determined cytotoxic effect of Se supports the theory of its cancer chemopreventive activity. In addition, the levels of 
most Se compounds that are 100 or 1000 higher than the normal blood concentration could find little use in cancer prevention or treatment because of the adverse effect on normal cells. Previous convincing findings of Se anticancer properties have led to the development of organoselenium compounds which have high chemopreventive activity and low toxicity, like xyleneselenocyanate (p-XSC) (EL-BAYOuMY et al., 1995). Coadministration of Se with other anticancer substances is another approach to bypass the toxicity of high concentrations of Se compounds to normal cells. Combinations of natural compounds with selenite or SeM were also found to be more effective than either of the substances alone (ABDUllaev \& GONZALEZ De MEJIA, 1996). IP and LisK (1996) have focused their research on the attainment of Se cancer chemopreventive effect with Se-eriched garlic, which has been shown to be superior to regular garlic in the suppression of mammary cancers in an animal model (IP et al., 1992). It is obvious that cancer prevention through Se-enriched, i.e. functional foods is the best way to utilize its chemopreventive potency on larger populations. All three chemical forms of Se investigated in the present work occur naturally in human nutrition, although there are differences regarding their levels in foods and absorption. From the little data on Se species in different foods (MUTANEN, 1986), it can be concluded that SeMet is probably the most frequent form of $\mathrm{Se}$ in human nutrition. A body of work also indicates that SeMet is more readily absorbed from the gastrointestinal tract than the other two chemical forms (LEVANDER et al., 1983; MCADAM et al., 1985).

Studies aimed at establishing Se provision to domestic animals (GAVRILOviC, 1981; GAVRILOVIĆ \& MATEŚIĆ, 1987; VuleniC et al., 1987) and humans (MANDIĆ et al., 1995; KLAPEC et al., 1998) in eastern Croatia point to suboptimal intakes, and deficiency diseases in domestic animals have been reported. Age-adjusted colorectal cancer mortality for the city of Osijek in 1994 is 15.8 , the corresponding data for US is 13.2 (source: www.cancermundial.com). If looked at from a perspective of Se intake, although one should always make such comparisons with caution because of numerous other factors affecting cancer prevalence, a higher incidence of cancer should be expected in eastern Croatia considering three to five times higher Se intakes in the USA (LONGNECKER et al., 1991; KLAPEC et al., 1998). Both our results and current knowledge on Se chemopreventive activity justify finding a proper way of raising Se provision to the population of eastern Croatia, hoping that immediate research will help clarify the role of this microelement in cancer prevalence in the area. 


\section{References}

ABDUllaEv, F. I. \& GONZALEZ DE MEJA, E. (1996): Inhibition of colony formation of HeLa cells by naturally occurring and synthetic agents. BioFactors, 5, 133-138.

AllawAy, V. H., KuBOTA, J., LOSEE, F. \& ROTH, M. (1968): Selenium, molybdenum, and vanadium in human blood. Arch. environ. Health, 16, 342-348.

ANUNDI, I., STÅHL, A. \& HÖGBERG, J. (1984): Effects of selenite on $\mathrm{O}_{2}$ consumption, glutathione oxidation and NADPH levels in isolated hepatocytes and the role of redox changes in selenite toxicity. Chem. biol. Interact., 50, 277-288.

APPEL, M. J. \& WOUTERSEN, R. A. (1996): Effects of dietary beta-carotene and selenium on initiation and promotion of pancreatic carcinogenesis in azaserine-treated rats. Carcinogenesis, 17, 1411-1416.

ARRICK, B. A. \& NATHAN, C. F. (1984): Glutathione metabolism as a determinant of therapeutic efficacy. A review. Cancer Res. 44, 4224-4232.

BATIST, G., KATKI, A. G., KleCKER, R. W., Jr. \& MYERS, C. E. (1986): Selenium-induced cytotoxicity of human leukemia cells: Interaction with reduced glutathione. Cancer Res., 46, 5482-5485.

BergGren, M. M., MANGIN, J. F., GaSDASKA, J. R. \& POWIS, G. (1999): Effect of selenium on rat thioredoxin reductase activity - Increase by supranutritional selenium and decrease by selenium deficiency. Biochem. Pharmacol., 57, 187-193.

CAFFREY, P. B. \& FRENKEL, G. D. (1991): Inhibition of cell colony formation by selenite: Involvement of glutathione. Mol. Pharmacol., 39, 281-284.

CLARK, C. L. (1985): The epidemiology of selenium and cancer. Fed. Proc., 44, 2584-2589.

Clark, C. L., CombS, G. F., Jr., Turnbull, B. W., Slate, E. H., Chalker, D. K., Chow, J., Davis, L. S., Glover, R. A., Graham, G. F., Gross, E. G., Krongrad, A., Lesher, J. L., Jr., Park, H. K., SANDERS, B. B., Jr., SMITH, C. L. \& TAYLOR, J. R. (1996): Effects of selenium supplementation for cancer prevention in patients with carcinoma of the skin. JAMA, 276, 1957-1963.

COMSTOCK, G. W., BUSH, T. L. \& HELZISOUER, K. (1992): Serum retinol, beta-carotene, vitamin E, and selenium as related to subsequent cancer of specific sites. Am. J. Epidemiol., 135, 115-121.

DAVIS, R. L. \& SPALlHOLZ, J. E. (1996): Inhibition of selenite-catalyzed superoxide generation and formation of elemental selenium $\left(\mathrm{Se}^{\circ}\right)$ by copper, zinc, and aurintricarboxylic acid (ATA). Biochem. Pharmacol., 51, 1387-1392.

DAVIS, C. D., FENG, Y., HEIN, D. W. \& FINLEY, J. W. (1999): The chemical form of selenium influences 3,2'-dimethyl-4-aminobiphenyl-DNA adduct formation in rat colon. J. Nutr., 129, 63-69.

DICKSON, R. L. \& TAPPEI, A. L. (1969): Reduction of selenocystine by cysteine or glutathione. Arch. Biochem. Biophys., 130, 547-550.

El-BAyOUMY, K. (1991): The role of selenium in cancer prevention, -in: DE VITA, V. T., HeLlman, S., ROSENBERG, S. S. (Eds). Practice of oncology. 4th ed., J. B. Lippincott, Philadelphia, pp. 1-15.

El-BAyOumy, K., UpadhyAYA, P., ChaE, Y. H., SOHN, O. S., RAO, C. V. Fiala, E. \& REDDY, B. S. (1995): Chemoprevention of cancer by organoselenium compounds. J. Cell Biochem., (Suppl. 22), 92-100.

ESAKI, N., NAKAMURA, T., TANAKA, H. \& SODA, K. (1982): Selenocysteine lyase, a novel enzyme that specifically acts on selenocysteine. J. biol. Chem., 257, 4386-4391

FEARON, E. R. \& VOGELSTEIN, B. (1990): A genetic model for colorectal tumorigenesis. Cell, 61, 759-767.

FiCO, M. E., POIRIER, K. A., WATRACH, A. M., WATRACH, M. A. \& MiLNER, J. A. (1986): Differential effects of selenium on normal and neoplastic canine mammary cells. Cancer Res., 46, 3384-3388.

GANTHER, H. (1968): Selenotrisulfides: Formation by the reaction of thiols with selenious acid. Biochemistry, 7, 2898-2905. 
GARBERG, P., StÅHL, A., WARHOlM, M. \& HÖGBERG, J. (1988): Studies of the role of DNA fragmentation in selenium toxicity. Biochem. Pharmacol., 37, 3401-3406.

GAVRILOVIC, B. (1981): O pojavi bolesti dudolikog srca medu svinjama u Požeškoj kotlini. (On the occurrence of mulberry heart disease in pigs in Požega valley.) Praxis Vet., 28, 331-335.

GAVRILOVIC, B. \& MATEŠIC, D. (1987): Importance of selenium quantity in soil and fodder in regard to the occurrence of some diseases in cattle, pigs, sheep and poultry in Yugoslavia. -in: COMBS, G. F., Jr, SPAllholz, J. E., LEVANDER, O. A. \& OldFIELD, J. E. (Eds), Selenium in biology and medicine. Van Nostrand Reinhold, New York, pp. 740-749.

GREEDER, G. A. \& MILNER, J. A. (1980): Factors influencing the inhibitory effect of selenium on mice inoculated with Ehrlich ascites tumor cells. Science, 209, 825-827.

HOCKENBERY, D. M., OltVAi, Z. N. Yin, X. M., Miliman, C. L. \& KORSMEYER, S. J. (1993): Bcl-2 functions in an antioxidant pathway to prevent apoptosis. Cell, 75, 241-251.

HORIUChI, N., NAKAGAWA, K., SASAKI, Y., MiNATO, K., FUJWARA, Y., NEZU, K., OHE Y. \& SAJO, N. (1988): In vitro antitumor activity of mitomycin $\mathrm{C}$ derivative (RM-49) and a new anticancer antibiotics (FK 973) against lung cancer cell lines determined by tetrazolium dye (MTT) assay. Cancer Chemother. Pharmacol., 22, 246-250.

IP, C. (1986): The chemopreventive role of selenium in carcinogenesis. J. am. Coll. Toxicol., 5, 7-20.

IP, C. \& GANTHER, H. E. (1990): Activity of methylated forms of selenium in cancer prevention. Cancer Res., 50, 1206-1211.

IP, C. \& GANTHER, H. E. (1993): Novel strategies in selenium cancer chemoprevention research. -in: BURK, R. F. (Ed.) Selenium in biology and human health. Springer-Verlag, New York, pp. 169-180.

IP, C. \& LISK, D. J. (1996): The attributes of selenium-enriched garlic in cancer prevention. Adv. exp. Med. Biol., 401, 179-187.

IP, C., HAYES, C., BUDNICK, R. M. \& GANTHER, H. E. (1991): Chemical form of selenium, critical metabolites, and cancer prevention. Cancer Res., 51, 595-600.

IP, C., LISK, D. J. \& STOEWSAND, G. S. (1992): Mammary cancer prevention by regular garlic and seleniumenriched garlic. Nutr. Cancer, 17, 279-286.

KAJANDER, O., HaRVima, R. J., KAUPPinen, L., AKerman, K. K., MartikAinen, H., PAJUla, R. L. \& KARENLAMPI, S. O. (1990): Effects of selenomethionine on cell growth and on S-adenosylmethionine metabolism in cultured malignant cells. Biochem. J., 267, 767-774.

KlapeC, T., MANDiC, M. L., GrgiC, J., PrimORAC, LJ., IkIC, M., LOVRIC, T., GrGiC, Z. \& HERCEG, Z. (1998): Daily dietary intake of selenium in eastern Croatia. Sci. total Environ., 217, 127-136.

LANFEAR, J., FleMING, J., WU, L., WEBSTER, G. \& HARRISON, P. R. (1994): The selenium metabolite selenodiglutathione induces p53 and apoptosis - Relevance to the chemopreventive effects of selenium. Carcinogenesis, 15, 1387-1392.

Levander, O. A., Alfthan, G., Arvilommi, H., Gref, C. G., Huttunen, J. K., Kataja, M., KOIVISTOINEN, P. \& PIKKARAINEN, J. (1983): Bioavailability of selenium to Finnish men as assessed by platelet glutathione peroxidase activity and other blood parameters. Am. J. clin. Nutr., 37, 887-897.

LIAO, J., WANG, D. X. \& TIAN, H. S. (1988): Sodium selenite inhibition of carcinogenesis in cultured rat trachea. Chin. med. J., 101, 204-208.

LONGNeCKer, M. P., TAYlor, P. R., LEVANDER, O. A., HOWE, S. M., VeIllon, C., MCADAM, P. A., PATterson, K. Y., HOlden, J. M., StAMPFER, M. J., MORRIS, J. S. \& WilletT, W. C. (1991): Selenium in diet, blood, and toenails in relation to human health in a seleniferous area. Am. J. clin. Nutr., 53, 1288-1294. 
LOWE, S. W., RULEY, H. E., JACKS, T. \& HOUSMAN, D. E. (1993): p53-dependent apoptosis modulates the cytotoxicity of anticancer agents. Cell, 74, 957-967.

LU, J., KAECK, M., JIANG, C., WILSON, A. C. \& THOMPSON, H. J. (1994): Selenite induction of DNA strand breaks and apoptosis in mouse leukemic L1210 cells. Biochem. Pharmacol., 47, 1531-1535.

Lu, J., JiAnG, C., KAECK, M., GANTHER, H., VAdHANAVIKIT, S., IP, C. \& THOMPSON, H. (1995): Dissociation of the genotoxic and growth inhibitory effects of selenium. Biochem. Pharmacol., 50, 213-219.

MANDIC, Z., MANDIC, M. L., GRGIC, J., HASENAY, D. \& GRGIC, Z. (1995): Selenium content of breast milk. Z. Lebensm. unters. Forsch., 201, 209-212.

MCADAM, P. A., LEVIS, S. A., HelZLSOUER, K., VeILlon, C, PATTERSON, B. \& LeVANDER, O. A. (1985): Absorption of selenite and L-selenomethionine in healthy young men using a ${ }^{74}$ selenium $\left({ }^{74} \mathrm{Se}\right)$ tracer. Fed. Proc., 44, 1671.

MCCONNELl, K. P., Broghamer, W. L., Jr., Blotcky, A. J. \& HuRT, O. J. (1975): Selenium levels in human blood and tissues in health and in disease. J. Nutr., 105, 1026-1031.

MEDINA, D. \& SHEPHERD, F. (1980): Selenium-mediated inhibition of mouse-mammary tumorigenesis. Cancer Lett., 8, 241-245.

MEDINA, D., LANE, H. W. \& TRACEY, C. M. (1983): Selenium and mouse mammary tumorigenesis: An investigation of possible mechanisms. Cancer Res., 43, (Suppl.), 2460s-2464s.

MILKS, M. M., WILT, S. R., ALI, I. I. \& COURI, D. (1985): The effects of selenium on the emergence of aflatoxin $\mathrm{B}_{1}$-induced enzyme-altered foci in rat liver. Fundam. appl. Toxicol., 5, 320-326.

MILNER, J. A. (1985): Effect of selenium on virally induced and transplantable tumor models. Fed. Proc., 44, 2568-2572.

MILNER, J. A. \& HSU, C. Y. (1981): Inhibitory effects of selenium on the growth of L1210 leukemic cells. Cancer Res., 41, 1652-1656.

MUTANEN, M. (1986): Bioavailability of selenium. Ann. clin. Res., 18, 48-54.

OVERVAD, K., THORLING, E. B., BJERRING, P. \& EBBESEN, P. (1985): Selenium inhibits UV-light-induced skin carcinogenesis in hairless mice. Cancer Lett., 27, 163-170.

PORTER, C. W., SUFRIN, J. R. \& KEITH, D. D. (1984): Growth inhibition by methionine analog inhibitors of S-adenosylmethionine biosynthesis in the absence of polyamine depletion. Biochem. Biophys. Res. Commun., 122, 350-357.

POwis, G., GaSDASKA, J. R., GASDASKa, P. Y., BERGgren, M. M., KirKPATRICK, D. L., ENGMAN, L., COTGREAVE, I. A., ANGULO, M., BAKER, A. (1997): Selenium and the thioredoxin system - Effects on cell growth and death. Oncology Res., 9, 303-312.

Redman, C., Xu, M.J., Peng, Y., SCott, J. A., Payne, C., Clark, C. L. \& Nelson, M. A. (1997): Involvement of polyamines in selenomethionine induced apoptosis and mitotic alterations in human tumor cells. Carcinogenesis, 18, 1195-1202.

Redman, C., Scott, J. A., Baines, A. T., Basye, J. L., Clark, L. C., Calley, C., Roe, D., Payne, C. M. \& NELSON, M. A. (1998): Inhibitory effect of selenomethionine on the growth of three selected human tumor cell lines. Cancer Lett., 125, 103-110.

Rum, G., ImRE, I., Sulle, C., SARUDI, I., KelEMEN, J. \& LASSU, Z. (1992): Selenium in blood of patients with colorectal cancer and neoplastic polyp. Acta physiol. Hungarica, 80, 275-279.

SAlonen, J. T., Alfthan, G., Huttunen, J. K. \& PUSKA, P. (1984): Association between serum selenium and the risk of cancer. Am. J. Epidemiol., 120, 342-349.

SCHRAUZER, G. N., WHITE, D. A. \& SCHNEIDER, C. J. (1977): Cancer mortality correlation studies. III. Statistical associations with dietary selenium intakes. Bioinorg. Chem., 7, 23-34. 
SCHRAUZER, G. N., WHITE, D. A. \& SCHNEIDER, C. J. (1978): Selenium and cancer: Effects of selenium and of the diet on the genesis of spontaneous mammary tumors in virgin inbred female $\mathrm{C} 3 \mathrm{H} / \mathrm{St}$ mice. Bioinorg. chem., 8, 387-396.

SHAMBERGER, R. J. (1985): The genotoxicity of selenium. Mutation Res., 154, 29-48.

SHAMBERGER, R. J. \& FROST, D. V. (1969): Possible protective effect of selenium against human cancer Can. med. Assoc. J., 100, 682.

SHAMBERGER, R. J. \& WILLIS, C. E. (1971): Selenium distribution and human cancer mortality. Crit. Rev. clin. Lab. Sci., 2, 211-221.

SINHA, R., SAID, S. K. \& MEDINA, D. (1996): Organic and inorganic selenium compounds inhibit mouse mammary cell growth in vitro by different cellular pathways. Cancer Lett., 107, 277-284.

Siwek, B., BAHBOUTh, E., SERrA, M. A., SABbiOnI, E., DE PAUW-GIllet, M. C. \& BASSLeER, R. (1994): Effect of selenium compounds on murine B16 melanoma cells and pigmented cloned pB16 cells. Arch. Toxicol., 68, 246-254.

SpallholZ, J. E. (1994): On the nature of selenium toxicity and carcinostatic activity. Free Radic. Biol. Med., 17, 145-164.

STEWART, M. S., DAVIS, R. L., WALSH, L. P. \& PENCE, B. C. (1997): Induction of differentiation and apoptosis by sodium selenite in human colonic carcinoma cells (HT29). Cancer Lett., 117, 35-40.

STEWART, M. S. SPAllholz, J. E., NELDNER, K. H. \& PENCE, B. C. (1999): Selenium compounds have disparate abilities to impose oxidative stress and induce apoptosis. Free Radic. Biol. Med., 26, $42-48$.

THOMPSON, H. J. \& BECCI, P. J. (1980): Selenium inhibition of N-methyl-N-nitrosourea-induced mammary carcinogenesis in the rat. J. natl. Cancer Inst., 65, 1299-1301.

VulinEC, M., ČULJAK, K., HAHN, V., PETRINEC, N., BEKER, D., NADAKOVIC, M. IVANUŠIC, M. (1987): O nekim bolestima domaćih životinja koje uzrokuje nestašica selena. (On certain diseases of domestic animals caused by selenium deficiency.) Praxis Vet., 35, 25-30.

WITHING, R. F., WEI, L. \& STICH, H. F. (1980): Unscheduled DNA synthesis and chromosome aberrations induced by organic selenium compounds in the presence of glutathione. Mutation Res., 78, 159-169.

Wilson, A. C., ThOMPSON, H. J., SCHEDIN, P. J., GIBSON, N. W. \& GANTHER, H. E. (1992): Effect of methylated forms of selenium on cell viability and the induction of DNA strand breakage. Biochem. Pharmacol., 43, 1137-1141.

WU, L., MCGARRY, L., LANFEAR, J. \& HARRISON, P. R. (1995): Altered selenium-binding protein levels associated with selenium resistance. Carcinogenesis, 16, 2819-2824.

YAN, L., YEE, J. A., BOYLAN, L. M. \& SPALlHOlZ, J. E. (1991): Effects of selenium compounds and thiols on human mammary tumor cells. Biol. trace Elem. Res., 30, 145-162.

YAN, L. \& SPALlHOLZ, J. E. (1993): Generation of reactive oxygen species from the reaction of selenium compounds with thiols and mammary tumor cells. Biochem. Pharmacol., 45, 429-437.

Zhu, Z. J., KIMURA, M., ITOKAWA, Y., AOKI, T., TAKAHASHI, J. A., NAKATSU, S., ODA, Y. \& KIKUCHI, H. (1996): Apoptosis induced by selenium in human glioma cell lines. Biol. trace Elem. Res., 54, $123-134$. 